\title{
Unconventional monetary policy: between the past and future of monetary economics*
}

\author{
Mattia Guerini** \\ OFCE-Sciences Po, Sophia-Antipolis, France and Sant'Anna School of Advanced Studies, Pisa, Italy \\ Francesco Lamperti*** \\ Sant'Anna School of Advanced Studies, Pisa and Fondazione Eni Enrico Mattei, Milano, Italy \\ Andrea Mazzocchetti**** \\ University of Genoa, Italy
}

In this paper we discuss some of the monetary policy issues that have involved major central banks worldwide since the 2008 financial crisis, and which remain open. We provide an excursus of the unconventional monetary policies adopted by central banks in the last decade, focusing on the European Central Bank and the Federal Reserve, and we discuss the rationale and efficacy of some unconventional monetary instruments, of inflation targeting and of central-bank independence. We also provide a perspective on possible future developments of monetary policy. We argue that while unconventional monetary policy was useful, there is still ample space for improvement: in the recessions to come, unconventional monetary policy will need to be better coordinated with fiscal, micro- and macro-prudential policies to provide more inclusive results that might positively affect the real economy beyond the financial system.

Keywords: unconventional monetary policies, inflation targeting, central-bank independence

JEL codes: $E 51, E 52, E 58, E 61$

'They were supposed to be exceptional and temporary - hence the term 'unconventional'. They risk becoming standard and permanent, as the boundaries of the unconventional are stretched day after day.'

C. Borio and A. Zabai (2016: 1)

\section{INTRODUCTION}

For contemporaneous monetary economists, the Great Recession will be remembered as the period when the common wisdom of monetary policy faced its greatest limitations. Indeed, during the liquidity-trap phase that followed the Great Recession, interest-rate adjustment

* MG acknowledges financial support from the European Union Horizon 2020 research and innovation programmes under grant agreement No 649186 (ISIGrowth) and No 640772 (DOLFINS). FL acknowledges financial support from EU-FP7 project IMPRESSIONS under grant No 603416. AM acknowledges support from EU-FP7 collaborative project SYMPHONY under grant No 611875.

** Email: mattia.guerini@sciencespo.fr.

*** Email: francesco.lamperti@santannapisa.it.

**** Email: andrea.mazzocchetti@edu.unige.it.

Received 30 March 2018, accepted 14 April 2018 
policies proved to be completely ineffective. Major central banks - including the Federal Reserve (Fed) and the European Central Bank (ECB) - have been compelled to design new monetary policy instruments and experience new monetary policy transmission channels. As a result, we distinguish between two classes of monetary policies (Borio/Zabai 2016): 'conventional' interest-rate policies and 'unconventional' balance-sheet policies. In this article we discuss some open monetary policy questions that are still undecided. Following a chronological order, we begin with the past by providing an evaluation of the events of the last decade in Section 2. Moving to the present, in Section 3 we discuss the economic rationale behind unconventional monetary policies and the extent to which they have affected the institutional arrangements of central-banking activity. In Section 4 we discuss possible future developments of unconventional monetary policies. Section 5 concludes.

\section{MONETARY POLICY IN THE GREAT RECESSION}

As soon as the financial crisis hit, at the end of 2007, the Fed intervened by lowering the main refinancing interest rate. Soon enough, however - in the third quarter of 2008 the zero lower bound (ZLB) became binding. The Fed responded then with unconventional monetary policies (UMPs) that increased the balance sheet of the central bank itself. In particular, the Fed adopted four tiers of asset purchase agreements (APAs), beginning with the acquisition of US $\$ 175$ billion of obligations and another US $\$ 1.25$ trillion of guaranteed mortgage-backed securities (MBSs) from Fannie Mae and Freddie Mac during the 2008-2010 period (see Table 1, overleaf). Then, in 2009 , it also extended this program to other long-term Treasury securities, spending US $\$ 300$ billion. Furthermore, in the 2010-2011 period, the Fed increased these acquisitions by US $\$ 600$ billion. Finally, starting from the end of 2012, when the Maturity Extension Programme ${ }^{1}$ was reaching its expiration day, the Fed started buying MBSs and other Treasury securities at a monthly rate of US $\$ 85$ billion per month, until the end of 2014. It was only at the beginning of 2015, when the US macroeconomic statistics returned to more acceptable levels, that all these purchases stopped.

Following the lead of the Federal Reserve, the ECB has introduced different forms of UMPs. Its very first actions were of limited scope and modest size. However, the strength of UMP practices was reinforced when the sovereign debt crisis affected several European Union (EU) members between 2011 and 2014. During the 1st and 2nd Covered Bonds Purchase programmes - which have respectively been implemented during the 2009-2010 and the 2011-2012 periods - a total amount of $€ 100$ billion was created by the ECB. ${ }^{2}$ After March 2015, however, the ECB substantially strengthened its quantitative easing (QE) plan, and started acquiring around $€ 60$ billion per month of sovereign bonds, corporate securities, asset-backed securities and other covered bonds. This plan was further reinforced in 2016 when the acquisition of bonds was augmented by up to $€ 80$ billion per month. The QE plan is ongoing.

All in all, the total assets of the Federal Reserve increased from around US\$1 trillion in 2007 to around US $\$ 4$ trillion today; similarly, the assets of the ECB increased from $€ 1.2$ trillion in 2007 to around $€ 3.5$ trillion today. However, the macroeconomic effects seem to be quite contrasted: while the UMPs apparently boosted the performance of the

1. Another form of UMP. For information on the Maturity Extension Programme, see https:// www.federalreserve.gov/monetarypolicy/maturityextensionprogram.htm.

2. Note that during the same period, the amount created by the Fed with the APAs was around 20 times higher. See Table 1. 
Table 1 Summary of policies and economic statistics in the US and the EU19 since 2008

\begin{tabular}{lll}
\hline & \multicolumn{1}{c}{ US } & \multicolumn{1}{c}{ EU19 } \\
\hline FP & ARRA (2009-2013): US\$0.8 trillion & SGP (2012-2014): inside 3\% \\
& USD & deficit \\
CMP & ZLB: since 2008-Q4 to 2015-Q4 & ZLB: since 2013-Q1 (still ongoing) \\
UMP & APA1 (2008): US\$1.4 trillion & CBPP1 (2009-2010): €60 billion \\
& APA2 (2009): US\$0.3 trillion & CBPP1 (2011-2012): €40 billion \\
& APA2 (2010-2011): US\$0.6 trillion & APP1 (2015): €60 billion/month \\
& APA3 (2012-2014): US\$85 billion/ & APP2 (2016): €80 billion/month \\
& month & $\Delta Y(2016): 2.3 \%$ \\
Outcome & $\Delta Y(2016): 2.3 \%$ & $\Delta P(2016):-0.2 \%$ \\
& $\Delta P(2016): 1.1 \%$ & $U(2016): 9 \%$ youth $20.9 \%)$ \\
\hline
\end{tabular}

Notes: FP = fiscal policy; CMP = conventional monetary policy; UMP = unconventional monetary policy; ARRA = American Recovery and Reinvestment Act; SGP = Stability and Growth Pact; $\mathrm{ZLB}=$ zero lower bound; $\mathrm{APA}=$ asset purchase agreement; $\mathrm{CBPP}=$ covered bonds purchase programme; $\mathrm{APP}=$ asset purchase programme.

Sources: CMP and UMP data have been drawn from Fed and ECB websites for the US and EU respectively; FP data have been drawn from BEA and Eurostat respectively; outcomes have been drawn from OECD statistics.

economy in the US, beneficial results for the EU are still weak. In our view, this might relate to the fact that the crisis hit the American economy when the debt-to-GDP ratio was relatively low, so that the QE policy was combined with a strong expansionary fiscal policy - the American Recovery and Reinvestment Act (ARRP - see Table 1). Instead, most of the EU economies entered the crisis endowed with debt-to-GDP ratios that were already high; this, combined with the forced compliance to the restrictive fiscal policy regime imposed by the Stability and Growth Pact (SGP), might help explain the different outcomes (Wilson 2012; Conley/Dupor 2013).

\section{UNDECIDED MONETARY ECONOMICS QUESTIONS}

We now move to the discussion of three different aspects of contemporary monetary policy: (i) the theoretical arguments standing behind the UMP practices and their empirical evaluations; (ii) the inflation targeting objective; and (iii) how UMP might impact the institutional arrangements of the central banks and in particular their independence.

\subsection{Unconventional monetary policy}

Conventional monetary policy tools have been focused on fixing the optimal cost of borrowing, with the final aim being that of directing the lending activity of banks, with money being endogenously created and injected into the economic system (Lavoie 1992). ${ }^{3}$ In general, unconventional monetary policy tools, and QE in particular, are instead instruments designed for governing the supply of credit when the optimal cost of borrowing is negative; they are supposed to be employed uniquely during liquidity-trap phases, when

3. See also Wicksell (1898) and Leijonhufvud (1979). 
the ZLB has been hit and the conventional price-based instrument becomes useless. With $\mathrm{QE}$, the central bank exogenously increases the monetary base by generating electronic cash and by providing liquidity to the financial institutions in exchange for some long-term assets (typically a mix of government bonds and low-rated, high-risk corporate bonds). This will in turn support the credit supply.

Underlying QE operations is a set of assumptions which claim that cleaning the balance sheets of the financial sector participants, and injecting fresh liquidity into the financial system, is extremely important to incentivize banks to acquire newly issued securities. And this growth in the demand for securities issued by the non-financial sector increases the inflationary pressures on the asset prices of non-financial corporations and lowers their long-term yields (step 1). Such a drop in long-term yields is said to increase - in turn - the demand for credit and private non-financial investments, stimulating economic growth and inducing some inflationary pressures (step 2) on commodity prices. Furthermore, as the theoretical argument continues, if QE is accompanied by forward guidance announcements aimed at improving the transparency of the central bank and at stabilizing the confidence of the institutional investors, the effects of QE can also become evident after a few lags because of the effects brought about by the expectations channel (Altavilla/Giannone 2017).

This set of hypotheses helps to explain why the empirical literature studying unconventional monetary policies has been focusing on the effects of QE, either on the long-term yields (step 1) or on macroeconomic fundamentals such as GDP and inflation (step 2). However, to identify causal relations between QE and the economic outcomes by means of commonly available time series approaches is an extremely difficult task. Researchers and central bankers working in this domain have been mostly interested in event studies. Using such an approach, Gagnon et al. (2011), Krishnamurthy/Vissing-Jorgensen (2011), Christensen/Rudebush (2012) and Duca (2013) provide somewhat converging evidence, validating the hypothesis that programmes of large asset purchases have reduced long-term interest rates, preventing high liquidity premiums from depressing financial institutions and financial markets. Swanson (2017), by contrast, compares the effects brought about by forward guidance and large-scale asset purchases in the United States ZLB period (2009-2015) and claims that while the former is more effective in the short run, the latter is a preferable instrument for the control of medium/long-term yields and for reducing interest-rate uncertainty.

In general, there is quite strong support for the evidence that most effectively implemented UMPs had a positive effect on financial stability, by increasing the liquidity of the financial system and by reducing both short- and long-term yields. ${ }^{4}$ These results provide support to the first step of the QE transmission mechanism.

Concerning the second step, part of the empirical literature claims that the adopted measures have generated positive returns also for the real economy in the US (Kapetanios et al. 2012; Baumeister/Benati 2013; Gambacorta et al. 2014; Bhattarai/Neely 2016). However, many scholars are still doubtful of the claims provided by this second stream of research, in particular because is difficult to isolate the effect that QE would have had without an active fiscal policy. Borio/Zabai (2016), for example, suggest the presence of a leak in the transmission of UMP measures from the financial sector to the real sector and claim that the mild short-term positive effects are likely to vanish in the long run, when the cost-benefit ratio of such policies will deteriorate. Rogoff (2017: 48) claims instead that 'many economists are rightly concerned that unconventional monetary policy tools are poor substitutes for conventional interest rate policy and might well have more side-effects'; this implies that

4. See also Altavilla/Giannone (2017) and Gorodnichenko/Ray (2017), among others. 
there is the possibility that these new tools are only imperfectly capable of managing private demand for credit and in turn inflation and output. ${ }^{5}$

All in all, our analysis of the events and our reading of the literature is similar to that of Martin/Milas (2012), who claim that while QE succeeded in reducing interest rates, the effects on the real economy were instead very mild in general.

\subsection{Inflation targeting}

Nowadays approximately 60 central banks worldwide are operating under an inflationtargeting (IT) regime and have an explicit inflation target that steers, alone or in combination with other objectives, their monetary policy decisions. ${ }^{6}$ The Fed and the ECB belong to this list, but with a major difference: while the unique mandate of the ECB is that of price stability (pure IT), the goal of the Fed is dual, as it aims at pursuing price stability as well as full employment.

Empirical evidence has mainly been supportive of the effectiveness of the IT framework in achieving low inflation and anchoring inflation expectations (Levin 2004; Vega/Winkelried 2005; Gürkaynak et al. 2010). However, it is worth noting that many countries adopted IT as part of a broader political and economic reform, involving a reinforcement of the institutional structure of policy-making (for instance, central-bank independence). Furthermore, the improvement in the technical skills within central banks, together with the increase in the availability and quality of macroeconomic and financial data sets that have accompanied the introduction of IT, may also contribute to explaining the improvement in monetary policy outcomes after the adoption of IT. Another possible explanation is that global cost-push factors were limited in the 1990s and early 2000s, which would explain why even countries that did not adopt IT benefited from a decrease in inflation rates.

In order to reduce the constraints of the ZLB, a number of prominent economists have advocated a higher inflation target. Among them, Lawrence Ball (2014) supports the increase of the target at 4 per cent, claiming that the reduction in the constraints on monetary policy arising from the ZLB would result in less severe downturns. Moreover, this benefit would come at a minimal cost, because a 4 per cent inflation rate leads to no significant harm to an economy.

The former Fed chairman, Ben Bernanke, also claims that a rise of the inflation target should be a change to be considered by central bankers, but he warns of the possible risks associated with higher inflation and the instability of inflation expectations. ${ }^{7}$ In addition, Blanchard et al. (2010) broached the idea that central banks should target an inflation rate of 4 per cent during expansion periods, to leave more space for nominal rate-cutting during recessions. But a possible increase of the target above the current level could lead to old problems as well as to new ones: Mishkin (2017) states that raising the inflation target to the 4 per cent level could jeopardize the hard-won success of reducing inflation after the Great Inflation of the 1970s, with the result that there would no longer be a credible nominal anchor. Critics of the higher target level also claim that a 4 per cent target might create

5. The claim by Rogoff (2017) is, however, to be contrasted with the results by Peersman (2011), who finds that the transmission channels of balance-sheet policies are similar to those of the standard interest-rate policies.

6. A full list of central banks' inflation targets is provided in http://www.centralbanknews.info/p/ inflation-targets.html.

7. See https://www.brookings.edu/blog/ben-bernanke/2016/09/13/modifying-the-feds-policyframework-does-a-higher-inflation-target-beat-negative-interest-rates/. 
distortions in the economy and that the costs might outweigh the intermittent benefits which would eventually arise by avoiding the ZLB in periods of strong distress.

IT seems to be an old solution to a new problem. In fact, while it could be argued that central banks successfully reduced inflation rates by means of low inflation targets in the 1990 s, they were not able to increase inflation in the aftermath of the crisis, especially in the EU. Therefore, a discussion on the revision of IT should be kept open and, possibly, find more space in the agenda, especially in view of future possible crises.

\subsection{Central-bank independence}

The term central-bank independence (CBI hereafter) can be subject to nuances of interpretation and can refer to different facets of central-banking and monetary policy (Balls et al. 2016). A minimal distinction shall be made between political and operational independence. The former refers to the degree of influence which elected politicians have over the central bank; the latter refers to the ability of the central bank to select and use monetary instruments with autonomy.

Since the late 1980s, in many advanced economies, central banks have been independent in the setting of monetary policy objectives. The Fed, for example, is an operationally independent government agency and its monetary policy decisions do not have to be approved by the President or by any legislative branch of the US government. However, it is politically accountable to the public and to Congress, which established maximum employment and stable prices as the key macroeconomic objectives. ${ }^{8}$ The ECB, by contrast, was founded in 1998 as an operationally and politically independent institution.?

The main rationale behind $\mathrm{CBI}$ is that of enhancing the credibility of the commitment toward a monetary policy based on IT. As a matter of fact, according to Bernanke, 'a central bank subject to short-term political influences would likely not be credible when it promised low inflation, as the public would recognize the risk that monetary policy makers could be pressured to pursue short-run expansionary policies that would be inconsistent with long-run price stability'. ${ }^{10}$

This consensus has been supported by strong theoretical and empirical foundations (Grilli et al. 1991; Eijffinger/de Haan 1996; de Haan et al. 2001; Klomp/de Haan 2010). In particular, the pre-crisis evidence indicated the importance of operationally independent monetary policy for developed countries (Cukierman 1992). However, as discussed in Section 2, the conduct of monetary policy in the aftermath of the global financial crisis has been different from pure IT. Hence also CBI (and in particular political $\mathrm{CBI})$ has been questioned: communications and a certain degree of coordination between central banks and governments became necessary. Lavoie (2017) argues that the crisis has highlighted the strict relation between governments and central banks for carrying out credit-easing operations and that the independence of the central banks is de facto an illusion and should not itself become a goal. Furthermore, the costs of political independence at the ZLB can be high. While in 'normal times' the central banks can do all that is necessary to stabilize macroeconomic outcomes without involvement in fiscal matters or intervention from governments, when conventional monetary policy based on interest rates is constrained by the ZLB, the central banks need to take aggressive unconventional

8. See https://www.federalreserve.gov/faqs/about_12799.htm.

9. The ECB is forbidden from purchasing government securities on primary markets; before the crisis, it also restrained itself (by tradition) from carrying out outright purchases of sovereign bonds on the secondary market.

10. See https://www.federalreserve.gov/newsevents/speech/bernanke20100525a.htm. 
monetary policy measures and coordinate with fiscal authorities on matters concerning economic stimulus and debt management reforms (Balls et al. 2016).

Although the coordination with fiscal authorities might undermine CBI on the political side, an operationally independent central bank would be free to coordinate with a finance ministry over the issues discussed earlier. Hence, CBI should be assessed while taking into consideration not only the objectives to be pursued, but also the macroeconomic background. In addition, since the range of responsibilities of central banks have been enriched - including mandates about financial supervision, financial stability, microand macro-prudential regulation matters - the need of coordination between fiscal and monetary policies has become crucial. Within this new institutional framework, the concept of central-bank independence is continuously evolving and might be further revisited in the years to come.

\section{THE FUTURE OF MONETARY POLICY}

With inflation targeting out of scope and the appropriate level of interaction and coordination between governments and central banks yet to be clearly defined, it is natural to wonder how the recently implemented UMPs might influence the future arrangements of monetary policy.

Compared with the very first experience with QE (implemented by the Bank of Japan in 2001), the current waves of UMP do not differ much with regard to the economic mechanisms that they engage and the scope that they aim at. The sharpest differences are that (i) as of today, they are lasting longer; (ii) they have been quantitatively more aggressive; and (iii) they have been applied by the central banks of different countries, but not at the same moment. QE cannot last forever, since it is grounded on the increase in the supply of money and on the storage of bad assets in the balance sheet of central banks; sooner or later central bankers will stop the practice and begin increasing interest rates. ${ }^{11}$ The questions are therefore: When? How much? Where?

When? On the one hand, low interest rates allowed restoring the functioning of the interbank markets, guaranteeing the required flexibility for financial institutions to comply with micro- and macro-prudential regulations. Furthermore, they sustained an increase in the number and size of transactions within interbank markets, especially in the EU. On the other hand, low interest rates dampen the profitability and the creditworthiness of all financial actors facing maturities on the liability side of their balance-sheets that are much longer than those on the asset side (for example, pension funds and insurance companies, which have already expressed their concerns with respect to the current state of affairs - see EIOPA 2014). The more central banks wait to raise interest rates, the more these institutions will be exposed, while the gains from stronger interconnections amongst financial institutions are doubtful (Battiston et al. 2016).

How much? Increasing interest rates is not immune to risks. Raising them would likely depress asset prices, which every day seem to beat another historical record (at least in the US) at the moment the authors are writing, while the real economy is growing at a far lower pace. On top of that, exchange-traded funds have dramatically increased in size

11. The Fed has already slightly increased the target federal funds rate during the last year and has already closed the Asset Purchases programmes. 
during the last five years (see the report by Ernst \& Young 2017). ${ }^{12}$ Assuming that asset markets are in a bubble, what would be the effect of an overly sharp or fast increase in policy rates? Should or should not a central bank lean against the financial cycle?

Where? Some authors, such as Swanson (2017), believe that an expansionary monetary policy affects the exchange rate via the relative amount of money denominated in domestic currency in the economy. Whether central banks in major economies should coordinate their policies is an issue which, in our opinion, should be discussed. Recent history shows that they do not tend to react in a synchronized way; this can be partly justified by the fact that their economies experience remarkably different timings and that a unique global business cycle does not exist. Nevertheless, how asynchronous QE programs affect exchange rates and real activities in different countries might deserve further attention.

\section{CONCLUSIONS}

The wave of unconventional monetary policies implemented in the aftermath of the Great Recession was deemed to be exceptional and temporary, but it became long-lasting and influential, possibly modifying the very role of central banking. Balance-sheet policies have a quasi-fiscal character and tend to cross the line between the government and the central bank. If a central bank actively engages into credit policies, it may be criticized for favouring one set of borrowers over another - a concern especially acute in the United States. And if it purchases government bonds on a large scale, it may be criticized for financing a specific government - a major concern in Europe. Leaving such critiques aside, in the future it might be fruitful to have fiscal and monetary policies which are better coordinated, especially in the EU (Pisani-Ferry/Wolff 2012). Furthermore, the Great Recession underlined the need for central banks to account for systemic risks and financial stability, thereby strengthening the links between monetary, micro- and macro-prudential policies. In such a perspective, monetary policy is likely to be more active in the future than it was in the past. Our hope is that the designers of the next wave of unconventional monetary policies will have learned from the experiences of the last ten years: these new policies should sustain firms and households rather than financial institutions, since the transmission channels of current unconventional monetary policies turned out to be weak or even ineffective.

\section{REFERENCES}

Altavilla, C., Giannone, D. (2017): The effectiveness of non-standard monetary policy measures: evidence from survey data, in: Journal of Applied Econometrics, 32(5), 952-964.

Ball, L. (2014): The case for a long-run inflation target of four percent, IMF Working Papers, No $14 / 92$.

Balls, E., Howat, J., Stansbury, A. (2016): Central bank independence revisited: after the financial crisis, what should the model central bank look like?, M-RCBG associate working paper series No 67.

Battiston, S., Caldarelli, G., May, R.M., Roukny, T., Stiglitz, J. (2016): The price of complexity in financial networks, in: Proceedings of the National Academy of Sciences, 113(36), 10031-10036.

12. In the popular press, see also https://www.forbes.com/sites/greatspeculations/2017/08/23/ record-inflows-boost-global-etf-assets-to-4-3-trillion-with-blackrock-leading-the-way. 
Baumeister, C., Benati, L. (2013): Unconventional monetary policy and the great recession: estimating the macroeconomic effects of a spread compression at the zero lower bound, in: International Journal of Central Banking, 9(2), 165-212.

Bhattarai, S., Neely, C. (2016): A survey of the empirical literature on U.S. unconventional monetary policy, Federal Reserve Bank of St. Louis Working Paper, No 2016-021A.

Blanchard, O., Dell'Ariccia, G., Mauro, P. (2010): Rethinking macroeconomic policy, in: Journal of Money, Credit and Banking, 42, 199-215.

Borio, C., Zabai, A. (2016): Unconventional monetary policies: a re-appraisal, BIS Working Papers No 570.

Christensen, J., Rudebusch, G. (2012): The response of interest rates to US and UK quantitative easing, in: Economic Journal, 122(564), 385-414.

Conley, T.G, Dupor, B. (2013): The American recovery and reinvestment act: solely a government jobs program?, in: Journal of Monetary Economics, 60(5), 535-549.

Cukierman, A. (1992): Central Bank Strategy, Credibility, and Independence: Theory and Evidence, Cambridge, MA: MIT Press.

De Haan, J., Eijffinger, S., Berger H. (2001): Central bank independence: an update of theory and evidence, in: Journal of Economic Surveys, 15, 3-40.

Duca, J. (2013): Did the commercial paper funding facility prevent a great depression style money market meltdown?, in: Journal of Financial Stability, 9(4), 747-758.

Eijffinger, S., De Haan, J. (1996): The political economy of central-bank independence, Tilburg Center for Economic Research Working paper, No 9587.

EIOPA (2014): Low interest rate environment stock taking exercise, European Insurance and Occupational Pensions Authority Working paper, No 14/103.

Ernst \& Young (2017): Reshaping around the investor - global ETF research 2017, URL: http:// www.ey.com/gl/en/industries/financial-services/ass-et-management/ey-global-etf-survey-2017.

Gagnon, J., Raskin, M., Remache, J., Sack, B.P. (2011): Large-scale asset purchases by the federal reserve: did they work?, in: Economic Policy Review, 17(1), 41-59.

Gambacorta, L., Hofmann, B., Peersman, G. (2014): The effectiveness of unconventional monetary policy at the zero lower bound: a cross-country analysis, in: Journal of Money, Credit and Banking, 46(4), 615-642.

Gorodnichenko, Y., Ray, W. (2017): The effects of quantitative easing: taking a cue from treasury auctions, NBER Working Paper, No 24122.

Grilli, V., Masciandaro, D., Tabellini, G., Malinvaud, E., Pagano, M. (1991): Political and monetary institutions and public financial policies in the industrial countries, in: Economic Policy, 6(13), 342-392.

Gürkaynak, R.S., Levin, A., Swanson, E. (2010): Does inflation targeting anchor long-run inflation expectations? Evidence from the U.S., UK, and Sweden, in: Journal of the European Economic Association, 8(6), 1208-1242.

Kapetanios, G., Mumtaz, H., Stevens, I., Theodoridis, K. (2012): Assessing the economy-wide effects of quantitative easing, in: The Economic Journal, 122(564), 316-347.

Klomp, J., de Haan, J. (2010): Inflation and central bank independence: a meta-regression analysis, in: Journal of Economic Surveys, 24(4), 593-621.

Krishnamurthy, A., Vissing-Jorgensen, A. (2011): The effects of quantitative easing on interest rates: channels and implications for policy, in: Brookings Papers on Economic Activity, 42(2), 215-287.

Lavoie, M. (1992): Foundations of Post-Keynesian Economic Analysis, Aldershot, UK and Brookfield, VT: Edward Elgar Publishing.

Lavoie, M. (2017): Rethinking monetary theory in light of Keynes and the crisis, in: Brazilian Keynesian Review, 2(2), 174-188.

Leijonhufvud, A. (1979): The Wicksell connection: variations on a theme, UCLA Economics Working Papers, No 165.

Levin, A., Natalucci, F., Piger, J. (2004): The macroeconomic effects of inflation targeting, in: Review, Federal Reserve Bank of St. Louis, 86(4), 51-80.

Martin, C., Milas, C. (2012): Quantitative easing: a sceptical survey, in: Oxford Review of Economic Policy, 28(4), 750-764. 
Mishkin, F.S. (2017): Rethinking monetary policy after the crisis, in: Journal of International Money and Finance, 73, 252-274.

Peersman, G. (2011): Macroeconomic effects of unconventional monetary policy in the euro area, CESifo Working Paper Series, No 3589.

Pisani-Ferry, J., Wolff, G. (2012): Is LTRO QE in disguise?, URL: https://voxeu.org-/article/ltroquantitative-easing-disguise.

Rogoff, K. (2017): Dealing with monetary paralysis at the zero bound, in: Journal of Economic Perspectives, 31(3), 47-66.

Swanson, E. (2017): Measuring the effects of federal reserve forward guidance and asset purchases on financial markets, NBER Working Papers, No 23311.

Vega, M., Winkelried, D. (2005): Inflation targeting and inflation behavior: a successful story?, in: International Journal of Central Banking, 1(3), 153-175.

Wicksell, K. (1898): Interest and Prices, New York: Sentry Press.

Wilson, D.J. (2012): Fiscal spending jobs multipliers: evidence from the 2009 American recovery and reinvestment act, in: American Economic Journal: Economic Policy, 4(3), 251-282. 